\title{
PENGARUH DOSIS PUPUK UREA TERHADAP PERTUMBUHAN DAN HASIL TANAMAN KAILAN (Brassica oleracea var. alboglabra)
}

\section{THE EFFECT OF UREA FERTILIZER DOSAGE ON THE GROWTH AND RESULTS OF KAILAN PLANT (Brassica oleracea var. alboglabra)}

\author{
Rina Susanti*, Rugayah, Setyo Widagdo, dan Darwin H. Pangaribuan \\ Jurusan Agroteknologi, Fakultas Pertanian, Universitas Lampung \\ J1 Sumantri Brojonegoro 1, Bandar Lampung 35145, Indonesia \\ *Email: rina.susanti1594@students.unila.ac.id
}

\begin{abstract}
Nitrogen fertilization is needed especially in leafy vegetables. The nitrogen source fertilizer that is often used by farmers is urea. This study aims to determine the best dosage of urea fertilizer on the growth and yield of kailan plants. This research was conducted at the Green House in the Integrated Field Laboratory, Faculty of Agriculture, University of Lampung. This research was conducted in October 2018 January 2019. This study used a randomized block design (RBD) with 5 single urea dosage treatments. The treatments of urea (u) used were without urea (u0), $150 \mathrm{~kg} / \mathrm{ha}(u 1), 300 \mathrm{~kg} / \mathrm{ha}(\mathrm{u} 2), 450 \mathrm{~kg} / \mathrm{ha}(\mathrm{u3})$, and $600 \mathrm{~kg} / \mathrm{ha}(\mathrm{u} 4)$. Each treatment was repeated 4 times so that there were 20 plots of experimental units. The results showed that the application of urea dosage had a significant effect on increasing leaf width, crown width, plant wet weight, and plant dry weight. The dosage of urea $300 \mathrm{~kg} / \mathrm{ha}$ (u2) showed the highest yield in increasing leaf width, crown width, plant fresh weight, and crown dry weight compared to other treatments.
\end{abstract}

Keywords: Dosage of urea, kailan, nitrogen

\begin{abstract}
ABSTRAK
Pemupukan nitrogen sangat dibutuhkan khususnya pada tanaman sayuran daun. Pupuk sumber nitrogen yang sering digunakan para petani adalah urea. Penelitian ini bertujuan untuk mengetahui dosis terbaik pupuk urea terhadap pertumbuhan dan hasil tanaman kailan. Penelitian ini dilaksanakan di Rumah Kacadan di Laboratorium Lapang Terpadu, Fakultas Pertanian, Universitas Lampung. Penelitian ini dilaksanakan pada Oktober 2018 Januari 2019. Penelitian ini menggunakan Rancangan Acak Kelompok (RAK) dengan 5 perlakuan tunggal dosis urea. Dosis urea $(\mathrm{u})$ yang digunakan adalah tanpa urea $\left(\mathrm{u}_{0}\right), 150 \mathrm{~kg} / \mathrm{ha}\left(\mathrm{u}_{1}\right), 300 \mathrm{~kg} / \mathrm{ha}\left(\mathrm{u}_{2}\right), 450 \mathrm{~kg} / \mathrm{ha}\left(\mathrm{u}_{3}\right)$, dan $600 \mathrm{~kg} / \mathrm{ha}\left(\mathrm{u}_{4}\right)$. Setiap perlakuan diulang sebanyak 4 kali sehingga terdapat 20 petak satuan percobaan. Hasil penelitian menunjukkan bahwa pemberian urea memberikan pengaruh nyata dalam meningkatkan lebar daun, lebar tajuk, bobot basah tanaman, dan bobot kering tanaman. Dosis urea $300 \mathrm{~kg} / \mathrm{ha}$ (u2) menunjukkan hasil yang paling tinggi dalam meningkatkan lebar daun, lebar tajuk, bobot segar tanaman, dan bobot kering tajuk tanaman dibandingkan dengan perlakuan lainnya.
\end{abstract}

Kata kunci: Dosis urea, kailan, nitrogen 


\section{PENDAHULUAN}

Kailan (Brassica oleraceae var. alboglabra) merupakan tanaman sayuran daun yang memiliki fungsi yaitu sebagai sayuran dan berperan dalam meningkatkan gizi masyarakat. Kailan memiliki banyak manfaat dan sebagai sumber utama mineral, protein, dan vitamin yang berguna untuk memelihara kesehatan tulangdangigi, pembentukan sel darah merah (hemoglobin), dan memelihara kesehatan mata. Protein yang terkandung dalam kailan bermanfaat untuk membentuk jaringan tubuh. Kailan juga mengandung karetonoid sebagai senyawa anti kanker. Kandungangizi dalam 100 g kailan yaitu Kalori 35 kal; protein $3 \mathrm{~g}$; lemak 0,40 g; karbohidrat $6,80 \mathrm{~g}$; serat 1,20 g; Ca 230 mg; P 56 mg; Fe 2 mg; Vitamin A 135 RE; vitamin B1 0,10 mg; vitamin B2 0,13; vitamin C $93 \mathrm{mg}$; dan air $78 \mathrm{mg}$ (Samadi, 2013).

Berdasarkan data dari Badan Pusat Statistik (2017), produksi kailan di Indonesia mencapai 627.598 ton dengan produktivitas sebesar 10,27 ton/ ha. Produktivitas kailan di provinsi Lampung sebesar 7,23 ton/ha(Badan Pusat Statistik, 2018). Berdasarkan data tersebut produktivitas tanaman kubis-kubisan di Lampung memiliki potensi untuk ditingkatkan.

Keberhasilan budidaya tanaman kailan dipengaruhi oleh faktor lingkungan,salah satunya yaitu tingkat kesuburan tanah untuk menyediakan unsur hara. Unsur hara paling tinggi yang dibutuhkan oleh tanaman adalah unsur N. Penambahan unsur hara dapat diberikan melalui pemupukan. Pemupukan nitrogen sangat dibutuhkan khususnya bagi tanaman sayuran daun dalam jumlah yang lebih besar (Sugito,1994). Pupuk nitrogen yang sering digunakan para petani adalah urea. Pupuk urea termasuk pupuk yang higroskopis (mudah menarik uap air). Keunggulan urea adalah kandungan $\mathrm{N}$ yang tinggi yaitu $46 \%$, larut dalam air, mudah diserap oleh tanaman, dan harganya relatif murah dibandingkan jenis pupuk nitrogen lainnya (Supriyadi dan Kardawati, 2017).

Dosis rekomendasi pupuk urea untuk tanaman kubis sebesar $3 \mathrm{~g} / \operatorname{tanaman}$ yang diberikan di sekeliling tanaman sejauh $5 \mathrm{~cm}$ dari batang. Pada tanaman sawi, dosis urea yang dianjurkan sebesar 3 g/tanaman, sedangkan pada tanaman lobak, dosis urea yang dianjurkan sebesar 6 g/tanaman (Sunarjono, 2016). Namun, belum terdapat informasi tentang pemberian dosis urea yang tepat pada tanaman kailan. Penelitian ini dilakukan untuk mengetahuidosis urea terbaik untuk meningkatkan pertumbuhan vegetatif tanaman kailan. Pemberian pupuk urea dalam dosis yang tepat diharapkan dapat memberikan pertumbuhan vegetatif maupun produksi tanaman yang lebih optimal.

\section{BAHAN DAN METODE}

Penelitian ini dilakukan di Rumah Kaca dan di Laboratorium Lapang Terpadu Fakultas Pertanian Universitas Lampung. Pelaksanaan penelitian ini dimulai pada Oktober 2018 hingga Januari 2019. Bahanbahan yang digunakanadalah benih kailan varietas winsa, kompos, pupuk urea, fungisida (Mankozeb 80\%), dan insektisida (Sipermetrin $50 \mathrm{~g} / \mathrm{L}$ dan Karbosulfan 200 g/L).

Penelitian ini dilakukan dalam Rancangan Acak Kelompok (RAK) dengan 5 perlakuan tunggal dosis urea. Dosis urea $(\mathrm{u})$ yang digunakan adalah tanpa urea (u0), $150 \mathrm{~kg} / \mathrm{ha}(\mathrm{u} 1), 300 \mathrm{~kg} / \mathrm{ha}(\mathrm{u} 2), 450 \mathrm{~kg} / \mathrm{ha}$ (u3), 
dan $600 \mathrm{~kg} / \mathrm{ha}(\mathrm{u} 4)$. Setiap perlakuan diulang sebanyak 4 kali sehingga terdapat 20 petak satuan percobaan dengan dengan populasi sebanyak 420 tanaman.

Tahapan penelitian dimulai dari penimbangan benih kailan sebanyak $4 \mathrm{~g}$ kemudian dilakukan inkubasi selama 1x24 jam pada suhu ruang sampai benih berkecambah. Benih yang telah diinkubasi disemai kedalam trey dengan menggunakan media tanam yaitu tanah dan kompos dengan perbandingan 1:1. Pemindahan tanaman kailan dilakukan pada 3 minggu setelah penyemaian. Tanaman kailan ditanam dalam bedengan dengan ukuran $2 \times 1$ m dengan jarak tanam 25 x $30 \mathrm{~cm}$. Pemupukan urea dilakukan pada saat tanaman berumur satu minggu setelah pindah tanam. Setiap kelompok tanaman yang merangkap sebagai ulangan terdapat lima perlakuan (1 kontrol dan 4 dipupuk). Lima jenis perlakuan tersebut adalah tanpa $\mathrm{N}$ (u0), $150 \mathrm{~kg} / \mathrm{ha}(\mathrm{u} 1), 300 \mathrm{~kg} / \mathrm{ha}(\mathrm{u} 2), 450 \mathrm{~kg} / \mathrm{ha}$ (u3), dan 600 kg/ha (u4). Pupuk diberikan dengan cara ditugal pada sisi kanan dan kiri tanaman kailan ( $\pm 5 \mathrm{~cm}$ dari tanaman).
Pengamatan dilakukan sejak 1 minggu setelah tanam hingga 4 minggu setelah tanam. Variabel yang diamati meliputi, tinggi tanaman, jumlah daun, panjang daun, lebar daun, lebar tajuk, diameter batang, bobot segar tanaman, panjang akar, bobot kering tajuk tanaman, dan bobot kering akar tanaman.

Data yang diperoleh pada setiap percobaan dilakukan analisis ragam dan dilanjutkan dengan uji polinomial orthogonal untuk mengetahui dosis urea terbaik terhadap semua perlakuan yang diterapkan pada kailan. Semua pengujian dilakukan pada taraf nyata 5\%.

\section{HASIL DAN PEMBAHASAN}

\section{Hasil}

Hasil penelitian menunjukkan bahwa pemupukan berbagai dosis urea tidak berpengaruh nyata terhadap tinggi tanaman kailan (Tabel 1).Pemberian pupuk urea dari 150 - 600kg/ha tidak meningkatkan tinggi tanaman kalian. Rata-rata tinggi tanaman kailan pada minggu ke 4 yaitu sebesar 7,94 cm dengan kisaran 7,29-8,64 cm.

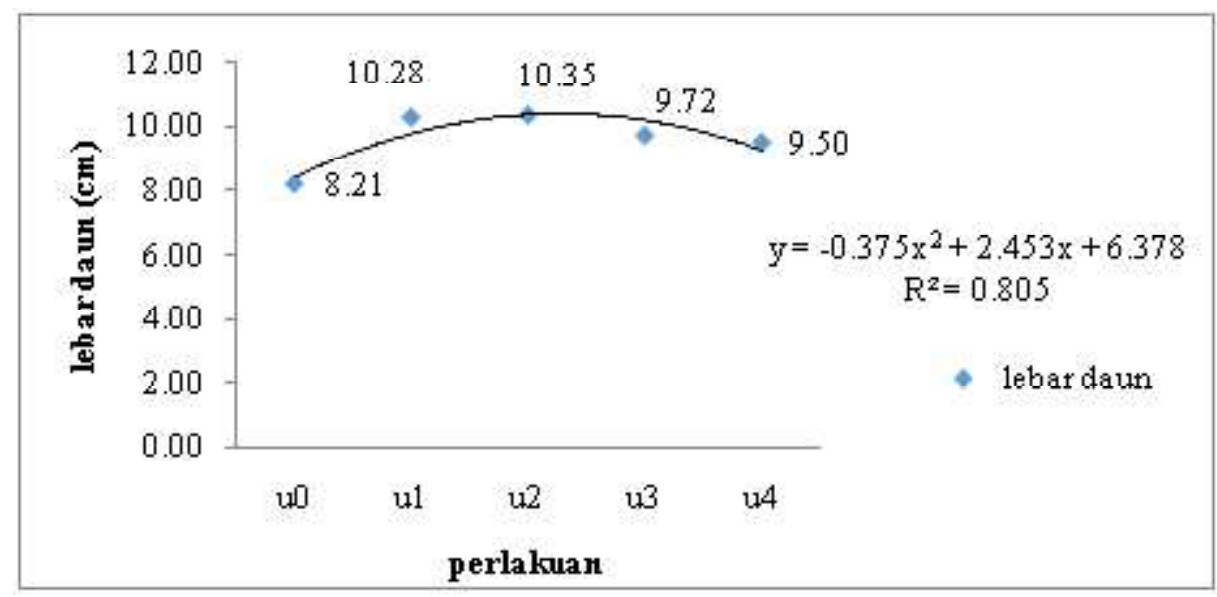

Gambar 1. Pengaruh dosis pupuk urea terhadap lebar daun kailan pada pada minggu ke 1 - 4

Keterangan : $\mathrm{u}_{0}=\operatorname{Kontrol}(\operatorname{tanpa~} \mathrm{N}) ; \mathrm{u}_{1}=$ Urea $150 \mathrm{~kg} / \mathrm{ha}$ atau $1,5 \mathrm{~g}$ per tanaman; $\mathrm{u}_{2}=$ Urea $300 \mathrm{~kg} / \mathrm{ha}$ atau 3,0 g per tanaman; $\mathrm{u}_{3}=$ Urea $450 \mathrm{~kg} / \mathrm{ha}$ atau $4,5 \mathrm{~g}$ per tanaman; $\mathrm{u}_{4}=$ Urea $600 \mathrm{~kg} / \mathrm{ha}$ atau $6,0 \mathrm{~g}$ per tanaman 
Hasil penelitian menunjukkan bahwa pemupukan berbagai dosis urea tidak berpengaruh nyata terhadap jumlah daun tanaman kailan (Tabel 1). Pemberian pupuk urea dari 150 - 600kg/ha tidak meningkatkan jumlah daun tanaman kalian. Rata-rata jumlah daun kailan pada minggu ke 4 yaitu sebesar 8,90 helai dengan kisaran 8,65-9,20 helai.

Hasil penelitian menunjukkan bahwa pemberian berbagai dosis pupuk urea tidak berpengaruh nyata terhadap panjang daun tanaman kailan (Tabel 1). Pemberian pupuk urea dari 150 - 600kg/hatidak meningkatkan panjang daun tanaman kailan. Rata-rata panjang daun kailan adalah 11,50 cm dengan kisaran $9,84-12,27 \mathrm{~cm}$.

Hasil penelitian menunjukkan bahwa pemberian berbagai dosis pupuk urea berpengaruh nyata terhadap lebar daun tanaman kailan (Tabel 1). Pengaruh dosis pupuk urea terhadap lebar daun kailan menunjukkan bahwa lebar daun meningkat secara kuadratik sampai mencapai titik maksimum pada dosis urea $327 \mathrm{~kg} / \mathrm{ha}$ yang menghasilkan lebar daun sepanjang $10,39 \mathrm{~cm}$.
Hasil penelitian menunjukkan bahwa pemberian berbagai dosis pupuk urea berpengaruh nyata terhadap lebar tajuk tanaman kailan (Tabel 1). Pengaruh dosis pupuk urea terhadap lebar tajuk kailan menunjukkan bahwa lebar tajuk meningkat secara kuadratik sampai mencapai titik maksimum pada dosis urea $329 \mathrm{~kg} / \mathrm{ha}$ yang menghasilkan lebar tajuk sepanjang 23,11 cm (Gambar 2).

Hasil penelitian menunjukkan bahwa pemberian berbagai dosis pupuk urea tidak berpengaruh nyata terhadap diameter batang tanaman kailan (Tabel 1). Pemberian pupuk urea dari 150 - 600kg/ha tidak meningkatkan diameter batang tanaman kailan. Ratarata diameter batang kailan adalah 1,24 cm dengan kisaran $0,99-1,39 \mathrm{~cm}$.

Hasil penelitian menunjukkan bahwa pemberian berbagai dosis pupuk urea tidak berpengaruh nyata terhadap panjang akar tanaman kailan (Tabel 1). Pemberian pupuk urea dari 150 - 600kg/ha tidak meningkatkan panjang akar kailan. Rata-rata panjang akar kailan 14,66 cm dengan kisaran 14,02-15,33 cm.

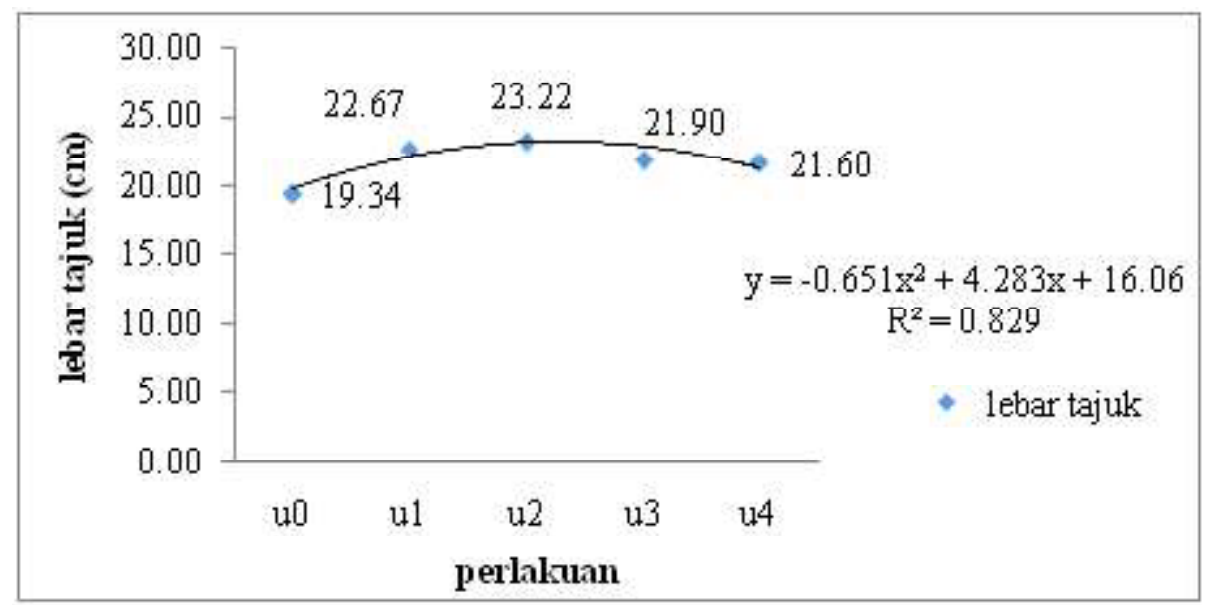

Gambar 2. Pengaruh dosis pupuk urea terhadap lebar tajuk kailan pada minggu ke 1-4

Keterangan : $\mathrm{u}_{0}=\operatorname{Kontrol}(\operatorname{tanpa~} \mathrm{N}) ; \mathrm{u}_{1}=$ Urea $150 \mathrm{~kg} / \mathrm{ha}$ atau $1,5 \mathrm{~g}$ per tanaman; $\mathrm{u}_{2}=$ Urea $300 \mathrm{~kg} / \mathrm{ha}$ atau 3,0 g per tanaman; $\mathrm{u}_{3}=$ Urea $450 \mathrm{~kg} / \mathrm{ha}$ atau $4,5 \mathrm{~g}$ per tanaman; $\mathrm{u}_{4}=$ Urea $600 \mathrm{~kg} / \mathrm{ha}$ atau $6,0 \mathrm{~g}$ per tanaman 
Tabel 1. Rekapitulasi hasil uji polinomial ortogonal tentang pemberian berbagai dosis urea terhadap tanaman

\begin{tabular}{lllllllllll}
\hline \multirow{2}{*}{ Perbandingan } & \multicolumn{10}{c}{ Signifikasi } \\
\cline { 2 - 10 } & JD & TT & PD & LD & LT & DB & PA & BS & BKT & BKA \\
\hline Linear & $0,33^{\text {tn }}$ & $0,05^{\text {tn }}$ & $2,43^{\text {tn }}$ & $1,73^{\text {tn }}$ & $3,35^{\text {tn }}$ & $1,85^{\text {tn }}$ & $0,62^{\text {tn }}$ & $1,56^{\text {tn }}$ & $3,80^{\text {tn }}$ & $0,00^{\text {tn }}$ \\
Kuadratik & $0,00^{\text {tn }}$ & $3,19^{\text {tn }}$ & $3,26^{\text {tn }}$ & $7,68^{*}$ & $12,84^{*}$ & $3,50^{\text {tn }}$ & $0,03^{\text {tn }}$ & $8,60^{*}$ & $7,70^{*}$ & $3,82^{\text {tn }}$ \\
\hline
\end{tabular}

Keterangan: Nilai F-tabel pada taraf $5 \%=4.75 ;{ }^{\text {tn }}=$ tidak berbeda nyata pada taraf $5 \% ;{ }^{*}=$ berbeda nyata pada taraf $5 \%$; $\mathrm{JD}=$ Jumlah Daun; $\mathrm{TT}=$ Tinggi Tanaman; $\mathrm{PD}=$ Panjang Daun; $\mathrm{LD}=$ Lebar Daun;LT= Lebar Tajuk; PA= Panjang Akar; DB= Diameter Batang; BS= Bobot Segar tanaman; BKT= Bobot Kering Tajuk; BKA= Bobot Kering Akar

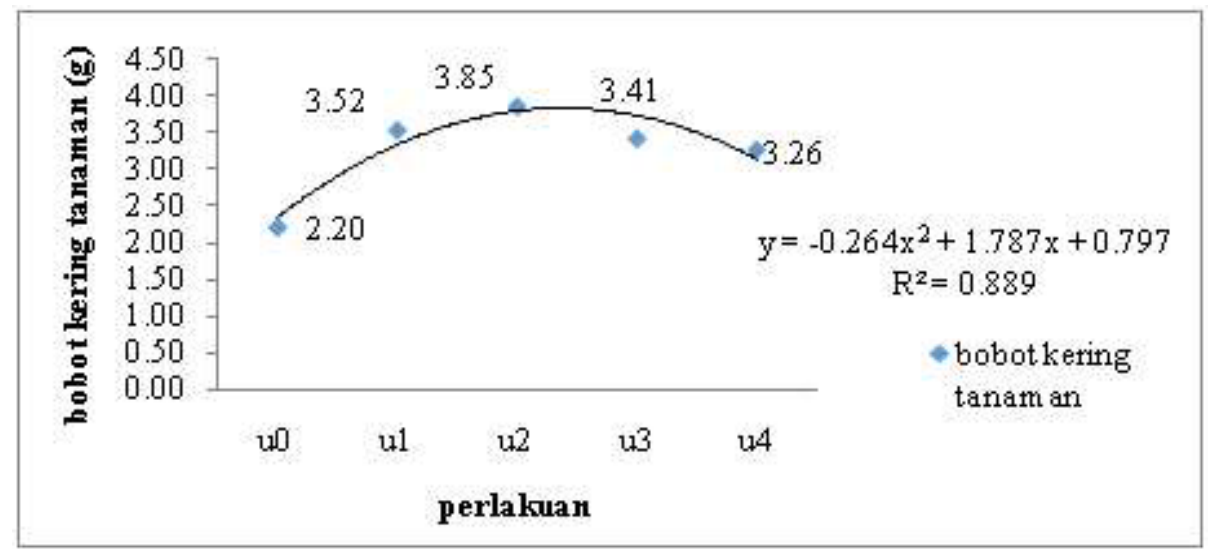

Gambar 3. Pengaruh dosis pupuk urea terhadap bobot kering tajuk kailan pada minggu ke-4

Keterangan : $\mathrm{u}_{0}=\operatorname{Kontrol}(\operatorname{tanpa} \mathrm{N}) ; \mathrm{u}_{1}=$ Urea $150 \mathrm{~kg} / \mathrm{ha}$ atau $1,5 \mathrm{~g}$ per tanaman; $\mathrm{u}_{2}=$ Urea $300 \mathrm{~kg} / \mathrm{ha}$ atau $3,0 \mathrm{~g}$ per tanaman; $\mathrm{u}_{3}=$ Urea $450 \mathrm{~kg} / \mathrm{ha}$ atau $4,5 \mathrm{~g}$ per tanaman; $\mathrm{u}_{4}=$ Urea $600 \mathrm{~kg} / \mathrm{ha}$ atau $6,0 \mathrm{~g}$ per tanaman

Hasil penelitianmenunjukkan bahwa pemberian berbagai dosis pupuk urea berpengaruh nyata terhadap bobot segar tanaman kailan (Tabel 1). Pengaruh dosis pupuk urea terhadap bobot segar tanaman kailan menunjukkan bahwa bobot segar tanaman meningkat secara kuadratik sampai mencapai titik maksimum pada dosis urea $320 \mathrm{~kg} / \mathrm{ha}$ yang menghasilkan bobot segar seberat 48,66 g atau 4,86 ton/ha (Gambar 3).

Hasil penelitian menunjukkan bahwa pemberian berbagai dosis pupuk urea berpengaruh nyata terhadap bobot kering tajuk tanaman kailan (Tabel 1). Pengaruh dosis pupuk urea terhadap bobot kering tajuk tanaman kailan menunjukkan bahwa bobot kering tajuk meningkat secara kuadratik sampai mencapai titik maksimum pada dosis urea $338 \mathrm{~kg} / \mathrm{ha}$ yang menghasilkan bobot kering tajuk seberat 3,82 g atau 0,38 ton/ha (Gambar 4).

Hasil penelitian menunjukkan bahwa pemberian berbagai dosis pupuk urea tidak berpengaruh nyata terhadap bobot kering akarkailan (Tabel 1). Pemberian pupuk urea dari 150 - 600kg/ha tidak meningkatkan bobot akar tanaman kailan. Rata-rata bobot kering akar kailan adalah 0,29 g dengan kisaran 0,20-0,39 g.

\section{Pembahasan}

Hasil penelitian menunjukkan bahwa pemberian urea berpengaruh nyata dalam meningkatkan lebar daun dan lebar tajuk kailan. Hal ini diduga karena kandungan $\mathrm{N}$ yang terdapat dalam urea dapat 
membantu dalam menambah lebar daun dan lebar tajuk tanaman kailan. Hasil penelitian ini memiliki pola yang sama dengan Istarofah dan Zuchrotus (2017), bahwa kandungan $\mathrm{N}$ dalam urea dapat mempengaruhi pertambahan lebar daun tanaman sawi hijau, selain itu pertambahan ukuran lebar daun juga terjadi karena pertumbuhan fasevegetatifyang sanga terat hubungannya dengan pembelahan, pemanjangan, dan diferensiasi sel. Menurut Prayudyaningsih dan Tikupadang (2008), nitrogen yang terkandung di dalam pupuk urea sebagai penyusun protein berperan dalam memacu pembelahan jaringan meritem dan merangsang pertumbuhan dan perkembangan daun sehingga berperan dalammenambah lebar daun dan tajuk tanaman.

Hasil penelitian menunjukkan bahwa pemberian urea berpengaruh nyata dalam meningkatkan bobot segardan bobot kering tanaman kailan. Hal ini diduga karena kandungan $\mathrm{N}$ yang terdapat dalam urea cukup optimal sehingga dapat membantu dalam penambahan bobot segardan bobot kering tanaman kailan. Bobot segar tanaman dipengaruhi oleh lebar daun dan lebar tajuk tanaman. Menurut Istarofah dan Zuchrotus (2017), pada tanaman sawi hijau bobot segar selain ditentukan oleh banyaknya daundan lebar daun untuk proses fotosintesis, dipengaruhi juga oleh ketersediaan unsurharaoptimaldi dalam tanah yang diserap oleh akar. Bobot segar tanaman meningkat karena tanaman mengandung protoplasma yang berfungsi sebagai penyimpan air dan $\mathrm{CO}_{2}$. Protoplasma dapat mengikat banyak air sehingga bobot segar akan meningkat.Menurut Prayudyaningsih dan Tikupadang (2008), bobot kering merupakan indikasi keberhasilan pertumbuhan tanaman, karena bobot kering merupakan petunjuk adanya hasil fotosintesis bersih yang dapat diendapkan setelah kadar airnya dikeringkan. Bobot kering menunjukkan kemampuan tanaman dalam mengambil unsur hara dari media tanam untuk menunjang pertumbuhannya.

Hasil penelitian ini menunjukkan bahwa pemberian urea dengan kisaran dosis $320-338 \mathrm{~kg} /$ hamemberikan hasil yang lebih baik dibandingkan perlakuan lainnya dalam rata-rata lebar daun, lebar

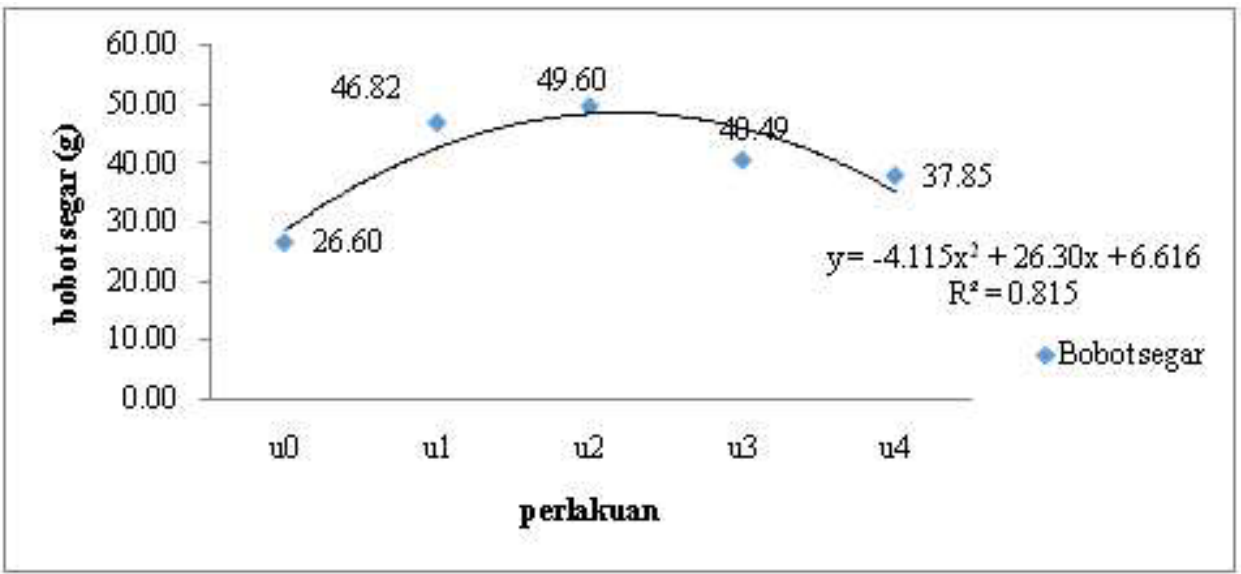

Gambar 4. Pengaruh dosis pupuk urea terhadap bobot segar kailan pada minggu ke-4

Keterangan $: \mathrm{u}_{0}=\operatorname{Kontrol}(\operatorname{tanpa~} \mathrm{N}) ; \mathrm{u}_{1}=$ Urea $150 \mathrm{~kg} / \mathrm{ha}$ atau $1,5 \mathrm{~g}$ per tanaman; $\mathrm{u}_{2}=$ Urea $300 \mathrm{~kg} / \mathrm{ha}$ atau 3,0 g per tanaman; $\mathrm{u}_{3}=$ Urea $450 \mathrm{~kg} / \mathrm{ha}$ atau $4,5 \mathrm{~g}$ per tanaman; $\mathrm{u}_{4}=$ Urea $600 \mathrm{~kg} / \mathrm{ha}$ atau $6,0 \mathrm{~g}$ per tanaman 
tajuk, bobot segar tanaman, dan bobot kering tanaman.Pemberian urea dosis $300 \mathrm{~kg} / \mathrm{ha}$ mampu menyuplai kebutuhan unsur hara nitrogen dalam proses pertumbuhan dan perkembangan tanaman kailan. Hasil penelitian ini memiliki pola yang sama dengan penelitian Hariodamar dkk. (2018), yang menyatakan bahwa pemberian urea $300 \mathrm{~kg} / \mathrm{ha}$ berpengaruh nyata dalam meningkatkan pertumbuhan dan hasil tanaman sawi dalam parameter tinggi tanaman, jumlah daun, lebar daun, bobot segar dan bobot kering tanaman.

Pada penelitian ini yaitu perlakuan urea $300 \mathrm{~kg} /$ ha menghasilkanrata-ratabobot segar tanaman sebesar 49,60 $\mathrm{g}$ atau 4,96 ton/ha,hasil tersebut lebih baik dari penelitian Filadola (2019), pada tanaman kailan dengan dosis urea $200 \mathrm{~kg} / \mathrm{ha}$ menghasilkan rata-rata bobot segar tanaman sebesar 37,66 g atau 3,76 ton/ha. Namun hasil tersebut masih di bawah penelitian Lauren (2019), pada tanaman kailan dengan dosis urea 200 $\mathrm{kg} /$ ha dengan penambahan pupuk dasar $\mathrm{P}$ dan $\mathrm{K}$ menghasilkan rata-rata bobot segar tanaman sebesar $72,9 \mathrm{~g}$ ata 7,29 ton/ha. Hasil penelitian tersebut menunjukkan bahwa pemberian urea dosis $300 \mathrm{~kg} / \mathrm{ha}$ lebih baik dibandingkan dosis urea $200 \mathrm{~kg} / \mathrm{ha}$ tetapi pemberian urea $200 \mathrm{~kg} / \mathrm{ha}$ dengan penambahan pupuk dasar $\mathrm{P}$ dan $\mathrm{K}$ memberikan pengaruh yang paling baik pada pertumbuhan dan hasil tanaman kailan.

Produktivitas kailan di provinsi Lampung sebesar 7,23 ton/ha (Badan Pusat Statistik,2018). Pada penelitian ini produktivitas kailan sebesar 4,96 ton/ha. Hasil tersebut masih kurang dari produktivitas di provinsi Lampung. Berbeda dengan hasil penelitian Lauren (2019), produktivitas kailan mencapai 7,29 ton/ ha. Hasil tersebut melebihi produktivitas di provinsi Lampung. Hasil penelitian sebelumnya Lauren (2019) lebih tinggi dibandingkan penelitian ini karena pada penelitian ini tidak diberikan pupuk dasar $\mathrm{P}$ dan $\mathrm{K}$ seperti penelitian sebelumnya. Unsur fosfor (P) berperan penting dalam transfer energi di dalam sel tanaman, mendorong perkembangan akar dan pembuahan lebih awal, memperkuat batang sehingga tidak mudah rebah, serta meningkatkan serapan $\mathrm{N}$ pada awal pertumbuhan (Syafruddin dkk., 2012). Kalium berperan penting dalam proses fotosintesis, respirasi, metabolisme tanaman, pembentukan karbohidrat, dan aktivitas enzim, sehingga kalium berpengaruh terhadap hasil produksi tanaman. Respon tanaman terhadap pemupukan kalium tidak hanya menhasilkan produksi yang lebih tinggi tetapi juga dapat berupa perbaikan kualitas hasil panen dan ketahan terhadap serangan penyakit (Liliana, 2017).

\section{KESIMPULAN}

Berdasarkan hasil penelitian, maka diperoleh kesimpulan sebagai berikut: Dosis urea mampu meningkatkan lebar daun, lebar tajuk, bobot segar tanaman, dan bobot kering tanaman. Pemberian urea $300 \mathrm{~kg} /$ ha menghasilkan lebar daun, lebar tajuk, bobot segar, dan bobot kering tajuk tanaman yang lebih tinggi dibandingkan denganperlakuan lainnya. Selisih dosis urea $300 \mathrm{~kg} /$ ha dibandingkan kontrol pada lebar daun yaitu $2,14 \mathrm{~cm}$, lebar tajuk sebesar $3,88 \mathrm{~cm}$, bobot segar tanaman sebesar 2,3 ton/ha, dan bobot kering tanaman sebesar 0,16 ton/ha. 


\section{DAFTAR PUSTAKA}

Badan Pusat Statistik. 2018. Statistik Tanaman Sayuran dan Buah-Buahan Semusim Indonesia Tahun 2017. BPS. Jakarta. $111 \mathrm{hlm}$.

Filadola, E. 2019. Pemberian Beberapa Jenis Pupuk Sumber Nitrogen Lepas Lambat pada Pertumbuhan Tanaman Kailan (Brassica alboglabra L.). (Skripsi). Fakultas Pertanian, Universitas Lampung. Bandar Lampung.

Hariodamar, H., M. Santoso, dan M. Nawawi. 2018. Pengaruh pemberian pupuk nitrogen terhadap pertumbuhan dan hasil 2 varietas tanaman sawi (Brassica juncea L.). Jurnal Produksi Tanaman. 6(9):2133-2141.

Istarofahdan S. Zuchrotus. 2017. Pertumbuhantanaman sawi hijau (Brassica juncea L.) dengan pemberian kompos berbahan dasar daun paitan (Thitonia diversifolia). Bio-site (3) : 1, ISSN: 2502-6178.

Lauren, L. 2019. Pemberian Beberapa Jenis Pupuk Sumber Nitrogen Lepas Lambat pada Pertumbuhan Tanaman Kailan (Brassica alboglabra L.) dengan Pemberian Pupuk Dasar P dan K. (Skripsi). Fakultas Pertanian, Universitas Lampung. Bandar Lampung.

Liliana, Y. 2017. Pengaruh Aplikasi Kombinasi Pupuk Kandang Ayam dan $\mathrm{KCl}$ terhadap
Pertumbuhan dan Hasil Produksi Jagung Manis (Zea mays Saccharata Sturt.). (Skripsi). Fakultas Pertanian, Universitas lampung. Bandar Lampung.

Prayudyaningsih, R. dan H. Tikupadang. 2008. Percepatan pertumbuhan Tanaman Bitti (Vitex Cofasuss Reinw) dengan aplikasi fungsi Mikorisa Arbuskula (FMI). Balai Penelitian Kehutanan Makassar. Makassar.

Samadi, B. 2013. Budidaya Insentif Kailan Secara Organik dan Anorganik. Pustaka Mina. Jakarta. 121 hlm.

Sugito, Y. 1994. Dasar-dasar Agronomi. Fakultas Pertanian Universitas Brawijaya. Malang.

Sunarjono, H.H. 2016. Bertanam 36 Jenis Sayur. Penebar Swadaya. Jakarta. $204 \mathrm{hlm}$.

Supriyadi dan F.T. Kadarwati. 2017. Efektifitas Pemupukan Nitrogen pada Kapas (Gossypium hirsutum L.). Balai Penelitian Tanaman Pemanis dan Serat. Malang. Hlm 154-158.

Syafruddin, Nurhayati, dan Wati. 2012. Pengaruh jenis pupuk terhadap pertumbuhan dan hasil beberapa varietas jagung manis. J. Floratek (7): $107-114$. 